\title{
Meditation on Friendship: Getting Lost in the Woods with Deena-Jamesville, NY . Judith Minty
}

You think I am like your grandmother

because I've been so far

North. But even a wolf marks territory, even she sets her teeth, lets no one beyond.

We stand at the edge

of winter. The desert beats in your blood.

I haven't lived here

long enough, though I tell you

I've been here before, though in fact

not exactly here. These are civilized woods.

You try to put on

the skin of this place, but it doesn't fit, the pelt

stretches and binds. Oh friend, we aren't animals after all.

We're troubled women, unable

to see clearly.

These are the oaks where, in October,

migrating robins rested. Now chattering half-truths, we step off the path into mud. We know better, still we wander a thread of a creek

to bark and dead leaves, musty soil.

We've not been touched for so long.

Almost dark, and we're turned

to repeating mistakes. I'm ashamed of my feet

stumbling, snapping twigs, grown clumsy as old women.

They sense the circles we've made.

We're lost and we know it.

There's no farmhouse, no cabin. We're locked in

these woods, the trees our markers,

the setting sun our compass. 
We need to speak from the heart again, to listen for the river. It's our way out, that water flowing. We need to be led downstream to the bridge, we need to reach the other side touching. 